\title{
1 A strontium isoscape of Italy for provenance studies
}

2 Federico Lugli ${ }^{1,2 *}$, Anna Cipriani ${ }^{2,3 *}$, Luigi Bruno ${ }^{2}$, Francesco Ronchetti ${ }^{2}$, Claudio Cavazzuti ${ }^{4,5}$, Stefano Benazzi ${ }^{1,6}$

1. Department of Cultural Heritage, University of Bologna, Via degli Ariani 1, 48121 Ravenna, Italy.

2. Department of Chemical and Geological Sciences, University of Modena and Reggio Emilia, 41125 Modena, Italy.

3. Lamont-Doherty Earth Observatory, Columbia University, Palisades, New York 10964, USA.

4. Dipartimento di Storia Culture Civiltà, University of Bologna, 40124 Bologna, Italia.

5. Department of Archaeology, Durham University, Durham, United Kingdom.

6. Max Planck Institute for Evolutionary Anthropology, Department of Human Evolution, 04103 Leipzig, Germany. *corresponding authors: federico.lugli6@unibo.it; anna.cipriani@unimore.it

\section{Abstract}

We present a novel database of environmental and geological ${ }^{87} \mathrm{Sr} /{ }^{86} \mathrm{Sr}$ values $(\mathrm{n}=1920)$ from Italy, using literature data and newly analysed samples, for provenance purposes. We collected both bioavailable and non-bioavailable (i.e. rocks and bulk soils) data to attain a broader view of the $\mathrm{Sr}$ isotope variability of the Italian peninsula. These data were used to build isotope variability maps, namely isoscapes, through Kriging interpolations. We employed two different Kriging models, namely Ordinary Kriging and Universal Kriging, with a geolithological map of Italy categorized in isotope classes as external predictor. Model performances were evaluated through a 10 -fold cross validation, yielding accurate ${ }^{87} \mathrm{Sr} /{ }^{86} \mathrm{Sr}$ predictions with root mean squared errors (RMSE) ranging between 0.0020 and 0.0024 , dependent on the Kriging model and the sample class. Overall, the produced maps highlight a heterogeneous distribution of the ${ }^{87} \mathrm{Sr} /{ }^{86} \mathrm{Sr}$ across Italy, with the highest radiogenic values $(>0.71)$ mainly localized in three areas, namely the Alps (Northern Italy), the Tuscany/Latium (Central Italy) and Calabria/Sicily (Southern Italy) magmatic/metamorphic terrains. The rest of the peninsula is characterized by values ranging between 0.707 and 0.710 , mostly linked to sedimentary geological units of mixed nature. Finally, we took advantage of the case study of Fratta Polesine, to underscore the importance of choosing appropriate samples when building the local isoscape and of exploring different end-members when interpreting the local Sr isotope variability in mobility and provenance studies. Our user-friendly maps and database are freely accessible through the Geonode platform and will be updated over time to offer a state-of-the-art reference in mobility and provenance studies across the Italian landscape.

Keywords: ${ }^{87} \mathrm{Sr} /{ }^{86} \mathrm{Sr}$ ratio; Kriging; isotope map; spatial modelling; traceability. 


\section{Introduction}

Geology is biological destiny: Whatever minerals land or are deposited in a place determine what or who can make a living there millions of years later.

The provenance of foods, artifacts, animals and individuals is a central topic in archaeology, ecology, forensic science and even in social sciences and humanities. A broad range of methods from genetics to inorganic chemistry can be used to disentangle the geographical origin or the movement of goods/people across the landscape, depending on the nature of the material itself (see e.g. Gregoricka, 2021; Tommasini et al., 2018). Isotope fingerprinting is applied to a variety of samples (e.g. biological tissues, artifacts, rocks, waters) using various isotope systematics of elements such as oxygen (e.g. Pellegrini et al., 2016; Pederzani and Britton, 2019), hydrogen (e.g. Soto et al., 2013), lead (e.g. Vautour et al., 2015; Smith et al., 2019; Killick et al., 2020), strontium (e.g. Bentley, 2006), and sulphur (e.g. Bataille et al., 2021) targeting the different materials depending on the element abundance in the sample and the geobiological process under investigation. In this sense, the radiogenic strontium ratio $\left({ }^{87} \mathrm{Sr} /{ }^{86} \mathrm{Sr}\right)$ is an excellent tracer of low temperature terrestrial processes for the abundance of elemental $\mathrm{Sr}$ and its mobility between the bio-, geo-, and hydro-spheres. While ${ }^{87} \mathrm{Sr}$ is the radiogenic-daughter of ${ }^{87} \mathrm{Rb},{ }^{86} \mathrm{Sr}$ is stable. Since both strontium and rubidium are ubiquitously present as trace elements within the Earth's crust, crustal rocks will thus acquire different ${ }^{87} \mathrm{Sr} /{ }^{86} \mathrm{Sr}$ ratios in relation to their age and to their initial $\mathrm{Sr}$ and $\mathrm{Rb}$ contents (Faure and Mensing, 2005). Ultimately, this results in a high-variability of the ${ }^{87} \mathrm{Sr} /{ }^{86} \mathrm{Sr}$ across the landscape (see e.g. Voerkelius et al., 2010). From the bedrock, Sr is transferred to soil, where it mixes with different local pools as surface waters, groundwaters and atmospheric depositions (Bentley, 2006). This is also why 'bioavailable' Sr (i.e. biologically available) might be isotopically different from the bedrock reservoir. In addition, the contribution of different minerals to the soil pool is variable due to i.e. differential weathering, $\mathrm{Sr} / \mathrm{Rb}$ content and solubility (Sillen et al., 1998). For example, the contribution of Sr-rich carbonates to the local bioavailable reservoir is much larger than e.g. a more resistant to weathering Sr-rich silicate.

Sr ions exchanges at the Earth surface carry the isotopic fingerprint shaped over time by the radioactive decay of

${ }^{87} \mathrm{Rb}$ and transfer certain isotopes proportions from rocks to soils and waters. From the soil and water, $\mathrm{Sr}$ ions enter the ecosystem reaching plants, through root uptake, and animals, through food and drinking water (Capo 
56 et al., 1998). In vertebrates, $\mathrm{Sr}$ is then mainly fixed in the hydroxyapatite of tooth and bone tissues substituting 57 calcium (Pors Nielsen, 2004). Across this pathway, mass-dependent Sr isotopic fractionation, as shown by e.g. the 58 relative depletion of the stable ${ }^{88} \mathrm{Sr} /{ }^{86} \mathrm{Sr}$ ratio along the food chain, is likely to occur (Knudson et al., 2010). 59 However, the fractionation of the ${ }^{87} \mathrm{Sr} /{ }^{86} \mathrm{Sr}$ ratio is deemed to be negligible and, anyhow, corrected during mass 60 spectrometry analyses as constant normalization to an internationally accepted ratio (Ehrlich et al., 2001).

61 Sr isotope data from biological samples of interest can be then compared with the local bioavailable Sr isotope ratio in order to understand whether the tissue formed locally or in a geologically different place, tracking the movements of people and goods through space and time (Ericson, 1985; Slovak and Paytan, 2012). Therefore, the subsequent step is to pin-point (more or less precisely) the specific geographic origin of the sample. In this sense, comparison with (inter)national geological maps can help to track the provenance of tissues formed on substrate whose isotopic ratio can be somehow predicted or expected, as for example in old metamorphic crystalline basements (i.e. highly radiogenic Sr isotope values) or depleted mantle-derived magmatic areas (low radiogenic $\mathrm{Sr}$ isotope values). Yet, a step-forward in isotope fingerprinting is the building of comparative isotopic maps that show the spatial distribution of the isotope signature (Bowen, 2010).

Using patchily-distributed measures of environmental samples, it is possible to build spatial models able to predict the local bioavailable ${ }^{87} \mathrm{Sr} /{ }^{86} \mathrm{Sr}$ ratio of a specific area. These data are then modelled through geostatistic tools in order to predict at best the ${ }^{87} \mathrm{Sr} /{ }^{86} \mathrm{Sr}$ ratio of areas with no available data. The resulting prediction maps are known as isoscapes. The utility of such implements has been demonstrated in several fields and they are today largely employed in provenance studies, as baselines for tracking the provenance of unknown specimens (e.g. Hobson et al., 2010; Muhlfeld et al., 2013; Song et al., 2014; Chesson et al., 2018; Colleter et al., 2021; Lazzerini et al., 2021). So far, national isoscapes have been produced for several European and extra-European countries, employing and testing several different methods for the spatial interpolation, including machine learning (Montgomery et al., 2006; Evans et al., 2010; Frei and Frei, 2011; Bataille and Bowen, 2012; Pestle et al., 2013; Hartman and Richards, 2014; Copeland et al., 2016; Kookter et al., 2016; Laffoon et al., 2017; Bataille et al., 2018; Hedman et al., 2018; Willmes et al., 2018; Adams et al., 2019; Ladegaard-Pedersen et al., 2020; Scaffidi and Knudson, 2020; Snoeck et al., 2020; Wang et al., 2020; Frank et al., 2021; Funck et al., 2021; Washburnet al., 2021; Zieliński et al., 2021). Although a large amount of 'bioavailable' Sr data was produced in the past, mostly linked to food provenance and archaeological studies, a national isoscape for Italy is still lacking. A first attempt has been done by Emery et al. 
84 (2018), where an inverse distance weighting (IDW) interpolation was tested using some literature data to produce

85 a preliminary Italian isoscape.

86 Here, we extended the database presented by Emery et al. (2018), using both novel and published data, and we

87 performed a robust geospatial modelling, employing Ordinary Kriging and Universal Kriging (Willmes et al.,

88 2018). Kriging is a widely used regression method in geostatistics and is based on the principle of 'spatial

89 autocorrelation' (Krige, 1951). This consists in best-fitting a mathematical function (i.e. variogram) to a

90 predetermined number of points with the aim of determining the output value for unknown locations and thus

91 generating a continuous surface map (Oliver and Webster, 1990). We produced maps of Italy exploiting the

92 Kriging methods and using an extensive dataset, which includes both 'bioavailable' and 'non-bioavailable' $\mathrm{Sr}$

93 isotope values (available at geochem.unimore.it/sr-isoscape-of-italy). The latter integrates bulk rock values from

94 magmatic and metamorphic rocks. We acknowledge that to understand the provenance of biological samples, the

95 best approach is to compare their isotopic fingerprint to bioavailable $\mathrm{Sr}$ isotope data. However, the inclusion of

96 sparse rock values allowed us to understand the 'weight' of the bedrock influence on the local Sr isotope

97 composition in specific areas of Italy. For this reason, we ultimately generated two maps, one with exclusively

98 bioavailable data and one that includes all the values from the dataset. Maps are freely accessible at 99 geochem.unimore.it/sr-isoscape-of-italy, through the GeoNode platform (geonode.org).

\section{Data and methods}

102

\subsection{Sample selection}

103 Strontium isotope data were collected $(\mathrm{n}=1831)$ from the literature (60 manuscripts) and categorized by source in six different clusters (Figure 1), namely 'plant', 'water', 'biomineral' (i.e. bones, teeth and bio-calcareous shells),

105 'food', 'soil' (including both exchangeable soil fractions and bulk soils) and 'rock' (mainly evaporites, metamorphic and magmatic rocks, and a few sedimentary bulk rocks). For each group, descriptive statistics analyses (i.e. mean, standard deviations and quantiles) were performed using Origin v. 2020 (see Table 1). We

108 incorporated in our dataset both bioavailable and non-bioavailable (namely rocks and bulk soils) Sr isotope data 109 and generated two maps (see below): one including the sole 'bioavailable' data and one including 'all' data 
110 ('bioavailable' + 'non-bioavailable'; see Table S1). This allowed us to obtain a broader overview of the Sr isotope

111 distribution across Italy.

Table 1. Descriptive statistics for the different sample categories.

\begin{tabular}{|c|c|c|c|c|c|c|c|}
\hline Category & N total & Mean & 2 SD & Mini mum & Medlan & Maximum & $\begin{array}{c}\text { Interquartile } \\
\text { Range (Q3 - Q1) }\end{array}$ \\
\hline Plant & 72 & 0.70881 & 0.00117 & 0.70778 & 0.70867 & 0.71122 & 0.00069 \\
\hline Water & 476 & 0.71005 & 0.01013 & 0.70354 & 0.70887 & 0.76384 & 0.00120 \\
\hline Blomineral & 471 & 0.70872 & 0.00182 & 0.70729 & 0.70866 & 0.71614 & 0.00094 \\
\hline Food & 296 & 0.70926 & 0.00282 & 0.70679 & 0.70899 & 0.72071 & 0.00071 \\
\hline Soll & 273 & 0.70994 & 0.00549 & 0.70528 & 0.7091 & 0.72379 & 0.00131 \\
\hline Rock & 332 & 0.71064 & 0.01081 & 0.70319 & 0.70898 & 0.753 & 0.00212 \\
\hline Whole dataset ('all') & 1920 & 0.70964 & 0.00734 & 0.70319 & 0.70888 & 0.76384 & 0.00105 \\
\hline
\end{tabular}

113 Novel data $(n=89)$ were generated from modern environmental and archaeological samples by solution MC-

114 ICPMS analyses. Samples include modern vegetation, archaeological and modern teeth, snails, waters, rocks and 115 soils. These samples are from areas where archaeological studies are in progress and thus were integrated into the 116 database. Five meteoric water samples collected from pluviometers located in the Emilian Apennine 117 (Montecagno, $44^{\circ} 19^{\prime} 57.76^{\prime \prime} \mathrm{N} ; 10^{\circ} 21^{\prime} 58.57^{\prime \prime} \mathrm{E}$ ) were also measured for their $\mathrm{Sr}$ isotopic composition. These values 118 were not included in the spatial model, but are presented as possible end-members for the Sr cycle in the biosphere, possibly helpful for future studies on Sr mixing (Table 2).

Table 2. Sr isotopes of meteoric waters measured in this study.

\begin{tabular}{|c|c|c|c|c|c|}
\hline Latitude & Longitude & Sampling date & Material & ${ }^{87} \mathbf{S r} /{ }^{86} \mathbf{S r}$ & 2 SE \\
\hline $44^{\circ} 19^{\prime} 57.76^{\prime \prime} \mathrm{N}$ & $10^{\circ} 21^{\prime} 58.57^{\prime \prime} \mathrm{E}$ & March 2016 & Meteoric water & 0.70848 & 0.00001 \\
\hline $44^{\circ} 19^{\prime} 57.76^{\prime \prime} \mathrm{N}$ & $10^{\circ} 21^{\prime} 58.57^{\prime \prime} \mathrm{E}$ & June 2016 & Meteoric water & 0.70873 & 0.00001 \\
\hline $44^{\circ} 19^{\prime} 57.76^{\prime \prime} \mathrm{N}$ & $10^{\circ} 21^{\prime} 58.57^{\prime \prime} \mathrm{E}$ & October 2016 & Meteoric water & 0.70882 & 0.00001 \\
\hline $44^{\circ} 19^{\prime} 57.76^{\prime \prime} \mathrm{N}$ & $10^{\circ} 21^{\prime} 58.57^{\prime \prime} \mathrm{E}$ & March 2017 & Meteoric water & 0.70924 & 0.00001 \\
\hline $44^{\circ} 19^{\prime} 57.76^{\prime \prime} \mathrm{N}$ & $10^{\circ} 21^{\prime} 58.57^{\prime \prime} \mathrm{E}$ & July 2017 & Meteoric water & 0.70897 & 0.00001 \\
\hline
\end{tabular}

\subsection{Solution MC-ICPMS}

122 Samples were processed at the Geochemistry Lab of the Department of Chemical and Geological Sciences

123 (University of Modena and Reggio Emilia) and at Durham University. All the reagents employed were of suprapur 124 grade (Modena) or bidistilled (Durham). Biominerals (i.e. teeth and snail shells) were cleaned with MilliQ water 125 and digested using concentrated $\mathrm{HNO}_{3}$. The bioavailable $\mathrm{Sr}$ fraction from soils instead was extracted using $0.25 \mathrm{M}$ 126 acetic acid. Bulk rocks samples were totally digested using a mixture of concentrated $\mathrm{HNO}_{3}$ and $\mathrm{HF}$. Waters were 127 filtered and acidified with $\mathrm{HNO}_{3}$ to a concentration of $3 \mathrm{M}$. After drying and re-dissolution by $3 \mathrm{M} \mathrm{HNO}_{3}$, all 128 samples were processed using the Eichrom $\mathrm{Sr}$-spec resin. The ${ }^{87} \mathrm{Sr} /{ }^{86} \mathrm{Sr}$ ratios were determined by Neptune MC129 ICPMS, one housed at the Centro Interdipartimentale Grandi Strumenti of the University of Modena and Reggio 

protocols are described in Lugli et al. (2017), Argentino et al. (2021) and Cavazzuti et al. (2019a, b). Repeated measures of NBS987 yielded an ${ }^{87} \mathrm{Sr} /{ }^{86} \mathrm{Sr}$ value of $0.710237 \pm 0.000011$ ( $2 \mathrm{SD} ; \mathrm{n}=18$; Modena $)$ and $0.710267 \pm$ et al., 2001).

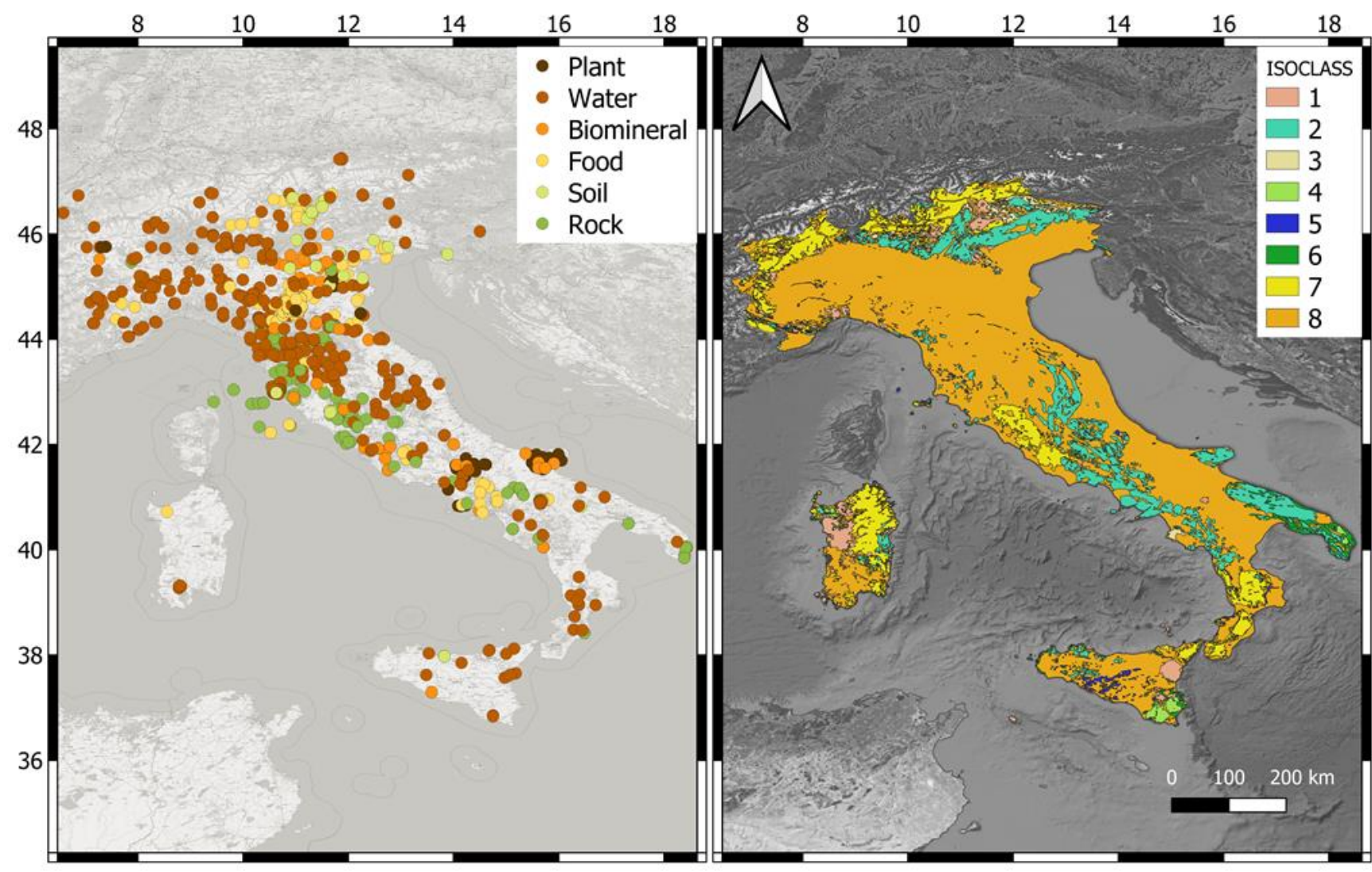

Figure 1. Left panel: locations of the data points considered in this study. Most of the data are from literature, with the addition of novel unpublished environmental/archaeological samples. All the samples in the 'plant', 'water', 'biomineral' and 'food' categories are considered 'bioavailable', in addition to 'soil' leachates. 'Rock' and bulk 'soil' are considered 'nonbioavailable'. This map was built in QGIS 3.8, exploiting the OpenStreetMap service. Right panel: Isoclass map of Italy that is a map of the Italian geolithologies classified according to their expected isotope values. This map is based on the geolithological map of Italy available at the Geoportale Nazionale

142 (http://wms.pcn.minambiente.it/ogc?map=/ms_ogc/wfs/Carta_geolitologica.map); the satellite map is provided by Google 143 through the QGIS QuickMapServices plug-in. Isoclass 1: plutonic and volcanic rocks related to MORB mantle magmatism of different ages. Isoclass 2: marine carbonate rock formations of Late Triassic, Cretaceous and Jurassic ages. Isoclass 3: Early and Middle Triassic and Paleogenic marine carbonate rocks. Isoclass 4: Early and Medium Miocene marine carbonate 
formations. Isoclass 5: Late Miocene carbonates. Isoclass 6: Pleistocene and Pliocene carbonate formations. Isoclass 7: old metamorphic and magmatic rocks of the crystalline basement and younger volcanics whose magmatism is affected by a radiogenic Sr isotope source. Isoclass 8: all the geolithologies not attributed to an isotope class due to their hybrid nature (i.e. siliciclastic rocks) or to their large $\mathrm{Sr}$ isotope variability (i.e., Permian to Devonian carbonates have a very wide range of $\mathrm{Sr}$ isotope ratios across several of our defined classes).

All the identified literature data and new data were grouped in an Excel worksheet and imported into SAGA 7.9 for geospatial modelling. We employed two different models to obtain the interpolated ${ }^{87} \mathrm{Sr} /{ }^{86} \mathrm{Sr}$ maps, namely Ordinary Kriging and Universal Kriging. The latter is drifted using a geological map of Italy as auxiliary predictor, similarly to the Kriging model with external drift of Willmes et al. (2018). However, unlike Willmes et al. (2018), where the isotope groups were defined using clustering techniques on the data itself, we relied on a simplified geological map of Italy (Figure 1), generated ad hocfor this project, combining geolithologies and expected isotope values of the rock formations. In particular, we defined eight isotope classes ('isoclass', Figure 1) taking advantage of: 1) the expected Sr isotope range of certain rock formations outcropping in the Italian peninsula as reported in the literature; 2) the categorization of geological units (i.e. metamorphic, magmatic, sedimentary, etc.) of the Italian geolithological map (published by the Geoportale Nazionale, pcn.minambiente.it; see also Figure S1); 3) the Sr isotope seawater curve of McArthur et al (2001), which in Italy finds wide application due to the continuous marine carbonate deposits from the Triassic to the Neogene preserved across the peninsula. Notably a relatively high number of isotope data is available in the literature for metamorphic and magmatic rocks across Italy, which have been measured to understand the geodynamic events that led to the formation of the Alps and Apennines and their emplacement at crustal level. Although most of these data were not included in the database, because no geolocalization was available, their isotope signature was used to define isoclasses as building blocks of the Italian

169 Sr isomap. In addition, several published Sr isotope data were measured on single mineral phases and therefore, being not representative of the bulk rock, could not be used for our purpose.

171 The range of $\mathrm{Sr}$ isotope values of the eight isoclasses is defined as follows: Isoclass 1 (expected ${ }^{87} \mathrm{Sr} /{ }^{86} \mathrm{Sr}<0.70682$ )

172 includes plutonic and volcanic rocks related to MORB mantle magmatism of different ages. Isoclass $2(0.70682<$ 173 expected ${ }^{87} \mathrm{Sr} /{ }^{86} \mathrm{Sr}<0.70783$ ) includes mainly marine carbonate rock formations of Late Triassic, Cretaceous and 174 Jurassic ages. Isoclass $3\left(0.70783<\right.$ expected $\left.{ }^{87} \mathrm{Sr} /{ }^{86} \mathrm{Sr}<0.70825\right)$ includes Early and Middle Triassic and Paleogenic 
175 marine carbonate rocks. Isoclass $4\left(0.70825<\right.$ expected $\left.{ }^{87} \mathrm{Sr} /{ }^{86} \mathrm{Sr}<0.70885\right)$ includes Early and Medium Miocene 176 marine carbonate formations. Isoclass $5\left(0.70885<\right.$ expected $\left.{ }^{87} \mathrm{Sr} /{ }^{86} \mathrm{Sr}<0.70903\right)$ includes mainly Late Miocene 177 carbonates. Isoclass $6\left(0.70903<\right.$ expected $\left.{ }^{87} \mathrm{Sr} /{ }^{86} \mathrm{Sr}<0.70920\right)$ includes Pleistocene and Pliocene carbonate 178 formations. Isoclass 7 (expected ${ }^{87} \mathrm{Sr} /{ }^{86} \mathrm{Sr}>0.70920$ ) includes old metamorphic and magmatic rocks of the 179 crystalline basement and younger volcanics whose magmatism is affected by a radiogenic Sr isotope source. Isoclass 1808 finally includes all the geolithologies that we were not able to attribute to an isotope class due to their hybrid 181 nature (i.e. siliciclastic rocks) or to their wide $\mathrm{Sr}$ isotope variability (i.e., Permian to Devonian carbonates have a 182 very wide range of $\mathrm{Sr}$ isotope ratios across several of our defined classes).

183 In attributing the isoclass to a particular geolithology or formation we confronted local rock values from literature 184 and, whenever possible, double checked their consistency with the bioavailable values of our database. When no 185 data were available, we considered the type of rock (i.e. mineralogy) and the age of formation. Initially, we defined 186 several more isoclasses in the $\mathrm{Sr}$ isotope range especially in the range between 0.7092 and very radiogenic values 187 (up to 0.75 ). However, we could attribute with certainty only a few data points from Sardinia to these classes, and 188 therefore we finally grouped all $\mathrm{Sr}$ isotope ratios $>0.7092$ in a unique class (isoclass 7 ). We stress that the 189 attribution of an isoclass has not been arbitrary and any attribution is either backed up by isotopic data or 190 consistent with a particular type of magmatism or deposition event (e.i. seawater curve for marine carbonates of 191 McArthur et al., 2001).

192 For geospatial modelling, the observed variograms were fit through a linear model, with a searching range of ca. $193180 \mathrm{~km}$. Similarly to what observed by Hoogewerff et al. (2019), the semivariograms obtained here showed a 194 cyclical-like structure, with a first maximum located at approximately $250 \mathrm{~km}$ (Figure S2). The prediction power 195 of the models was evaluated using a 10-fold cross-validation method through SAGA 7.9 (Table 3). The 196 interpolated Kriging models were imported into QGIS 3.18 to generate the final distribution maps (freely available 197 online at geochem.unimore.it/sr-isoscape-of-italy). We note here that Sardinia was excluded from the Ordinary 198 Kriging due to the low number of data from the area.

Table 3.10-fold cross validation results for Kinging model performances trough SAGA 7.9.

\begin{tabular}{|c|c|c|c|c|c|}
\hline \multirow{2}{*}{ Model } & Dataset & N. data points & RMSE & $\begin{array}{c}\text { Normalized } \\
\text { RMSE (\%) }\end{array}$ & $\mathbf{R}^{\mathbf{2}(\%)}$ \\
\hline \multirow{2}{*}{ Ordinary Kiring } & 'bioavailable' & 1568 & 0.0021 & 3.5 & 59.5 \\
\cline { 2 - 6 } & 'all' & 1920 & 0.0024 & 3.9 & 66.0 \\
\hline \multirow{2}{*}{ Universal Kiring } & 'bioavailable' & 1568 & 0.0020 & 3.4 & 59.0 \\
\cline { 2 - 6 } & 'all' & 1920 & 0.0022 & 3.6 & 69.7 \\
\hline
\end{tabular}




\section{Results and discussion}

201

202

203

204

205

206

207

208

209

210

211

212

213

214

215

216

217

218

219

220

221

222

223

224

225

226

\subsection{Data description and distribution}

Descriptive statistics for the data considered in this study are reported in Tables 1 and $S 1$ and summarized in Figures 2 and S3. When categorized, the 'rock' group has as expected the larger variance of the whole dataset, with $\mathrm{a}^{87} \mathrm{Sr} /{ }^{86} \mathrm{Sr}$ ranging from 0.70319 to 0.75300 (Figure 2). This group also shows the averagely highest $\mathrm{Sr}$ isotope values (0.7106). On the contrary, plants and biominerals are characterized on average by the lowest Sr isotope values (0.7087-0.7088). The most extreme values of the dataset are found within 'rock' (0.70319) and 'water' (0.76384) groups (see Table 1). Bioavailable samples show an average ${ }^{87} \mathrm{Sr} /{ }^{86} \mathrm{Sr}$ ratio of $0.70941 \pm 0.00632(2 \mathrm{SD})$, and span between 0.70354 and 0.76384 , with a median value of 0.70883 . The kernel density distribution of the bioavailable data is strongly asymmetric and leptokurtic (skewness $=8.14$; kurtosis $=99.16$ ). Notably, the nonbioavailable samples, including all the rocks and bulk soils, display an average ${ }^{87} \mathrm{Sr} /{ }^{86} \mathrm{Sr}$ ratio of $0.71069 \pm 0.01054$ (2 SD), ranging between 0.70319 and 0.75300 , with a median value of 0.70900 (Table S1). The distribution of the non-bioavailable dataset is asymmetric but less leptokurtic than the bioavailable (skewness = 3.93; kurtosis = 22.40). Yet, we stress that the number of non-bioavailable data $(n=352)$ here considered is remarkably lower than the data in the bioavailable dataset $(\mathrm{n}=1568)$, potentially influencing our observations on the data. Similarly, the uneven spatial distribution of 'non-bioavailable' samples across Italy certainly influenced data evaluations and use for this class. ${ }^{87} \mathrm{Sr} /{ }^{86} \mathrm{Sr}$ ratios of the bioavailable samples were also exploratively plotted against latitude and longitude (Figure 3), searching for potential correlations between these variables. However, no statistically significant trend was observed (both $\mathrm{R}^{2}<0.1$ ). Yet, the two graphs clearly show a preferential distribution of the highest radiogenic Sr values northwards (latitude $44-47^{\circ} \mathrm{N}$ ) and eastwards (longitude $7-12^{\circ} \mathrm{E}$ ). This is expected due to the presence of old metamorphic and magmatic rocks in the Alpine area and magmatic-metamorphic provinces in Central Italy (Tuscany, Latium), and also evident when data are plotted by Italian macroregions (Figure 2).

Five meteoric waters, not included in the previous statistics evaluations (and the interpolated maps) range between 0.70848 and 0.70924 , and represent an end-member of the Sr bioavailable cycle. These five waters were sampled from the same pluviometer located in the Emilian Apennine, and they were seasonally collected ca. 3-to-5 months apart from each other. These data highlight a remarkable temporal variability of the local rainwater likely due to 
228 bioavailable Sr (Négrel et al., 2007).
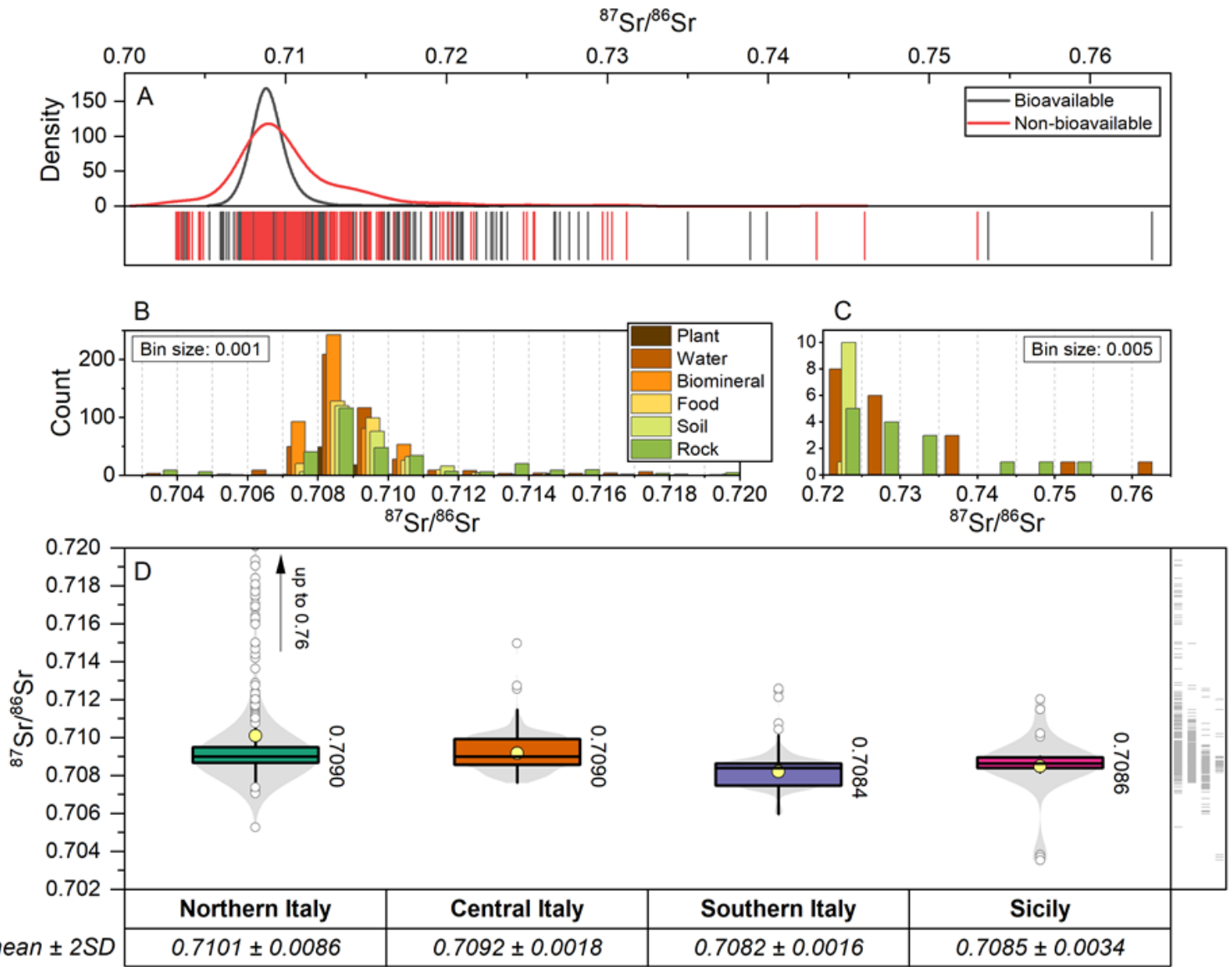

Figure 2. Data exploration. A) Kernel density estimation of bioavailable $(\mathrm{n}=1568)$ vs. non-bioavailable $(\mathrm{n}=352){ }^{87} \mathrm{Sr} /{ }^{86} \mathrm{Sr}$ data. B) Superimposed histogram representing the different sample categories between 0.702 and 0.720 , with a bin size of 0.001. C) Superimposed histogram of the different sample categories between 0.720 and 0.77 , with a bin size of 0.005 . Note that the $\mathrm{y}$-scale ranges of the histograms ('count') are different. D) Sr isotope data grouped by geographical areas (macroregions) of Italy, defined according to the National Institute of Statistics (istat.it); median values are labelled close to the box plots; average values $\pm 2 \mathrm{SD}$ are also reported. 

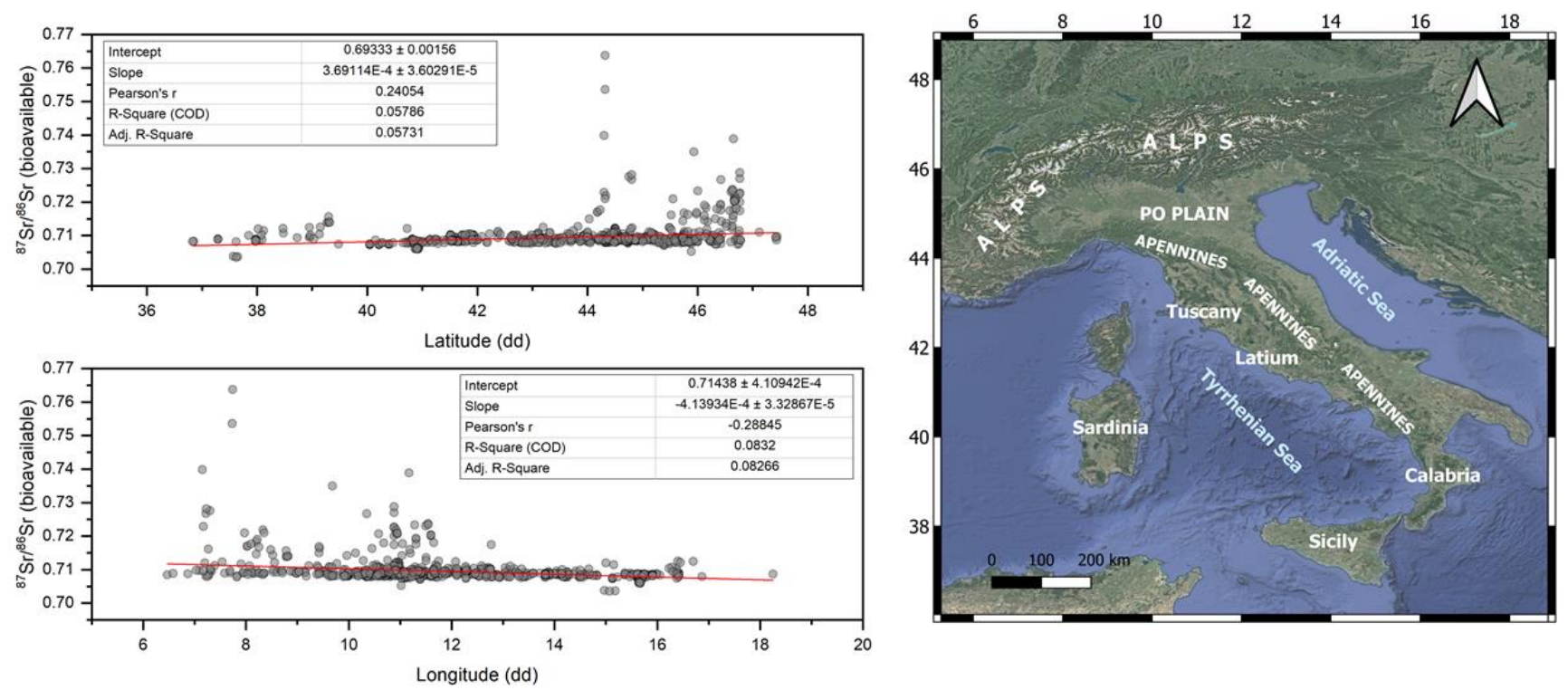

Figure 3. The ${ }^{87} \mathrm{Sr} /{ }^{86} \mathrm{Sr}$ ratios plotted against latitude and longitude (decimal degrees). No significant linear trend appears; 238 however, most of the radiogenic Sr data are latitudinally distributed northwards and longitudinally eastwards. Graphs and 239 linear trends were produced using Origin v. 2020. Right panel: a geographic map of Italy is reported as reference; main areas cited in the manuscript are labelled.

243 The isoclass map of Italy (Figure 1) allows a first order distinction between the radiogenic $\mathrm{Sr}$ isotope provinces, 244 related to the 'old' crustal and radiogenic Sr isotope magmatism units mainly present in the Alps, Calabria, 245 Sardinia and Central Italy, and the unradiogenic provinces related to the depleted mantle magmatism mainly in 246 the Southern Alps and Sicily. Yet, more information can be gathered through the isoscape maps (Figures 4 and 5).

247 These were built modelling the two datasets, namely 'bioavailable' and 'all'. Each figure includes two maps 248 obtained with two distinct Kriging approaches: Ordinary and Universal with external drift. The evaluation of 249 performance of the two models is reported in Table 3. Both methods produced satisfying results, with relatively 250 low normalized root mean squared errors (NRMSE $\sim 3-4 \%$ ), explaining between $\sim 60$ and $\sim 70 \%$ of the isoscape 251 variance $\left(\mathrm{R}^{2}\right)$. In general, Universal Kriging (with eternal drift) seems to outperform Ordinary Kriging, although 252 the difference is not remarkable (Table 3). The lowest RMSE is observed for the 'bioavailable' Universal Kriging, 253 and is equal to 0.0020; instead, the highest RMSE (0.0024) was obtained for the 'all' Ordinary Kriging model. 254 Altogether, the presence of non-bioavailable (un)radiogenic end-members in the 'all' database seems to limit the 
prediction power of the Kriging method, both in terms of data over-fitting (higher $\mathrm{R}^{2}$ ) and worse variogram modelling (see also Figure S4). To further evaluate the prediction of our modelling we measured the prediction standard errors for the Kriging maps (Figure S4). Both models (i.e. Ordinary and Universal) show similar standard prediction errors, ranging from ca. 5E-7 to 5E-6 for the 'bioavailable' dataset and from 2E-7 to 2E-5 for the 'all' dataset. These errors are low when compared with other spatial interpolation presented in literature for isoscapes (e.g. Willmes et al., 2018; Adams et al., 2019; Wang et al., 2020). Such low values are possibly related to the high number of samples considered in this study (total $\mathrm{n}=1920$ ), evenly distributed across Italy (see Figure 1), compared to the available literature studies. Largest errors indeed can be found in Sicily and Sardinia, where the number of samples is significantly lower than in other areas (Figure S4).
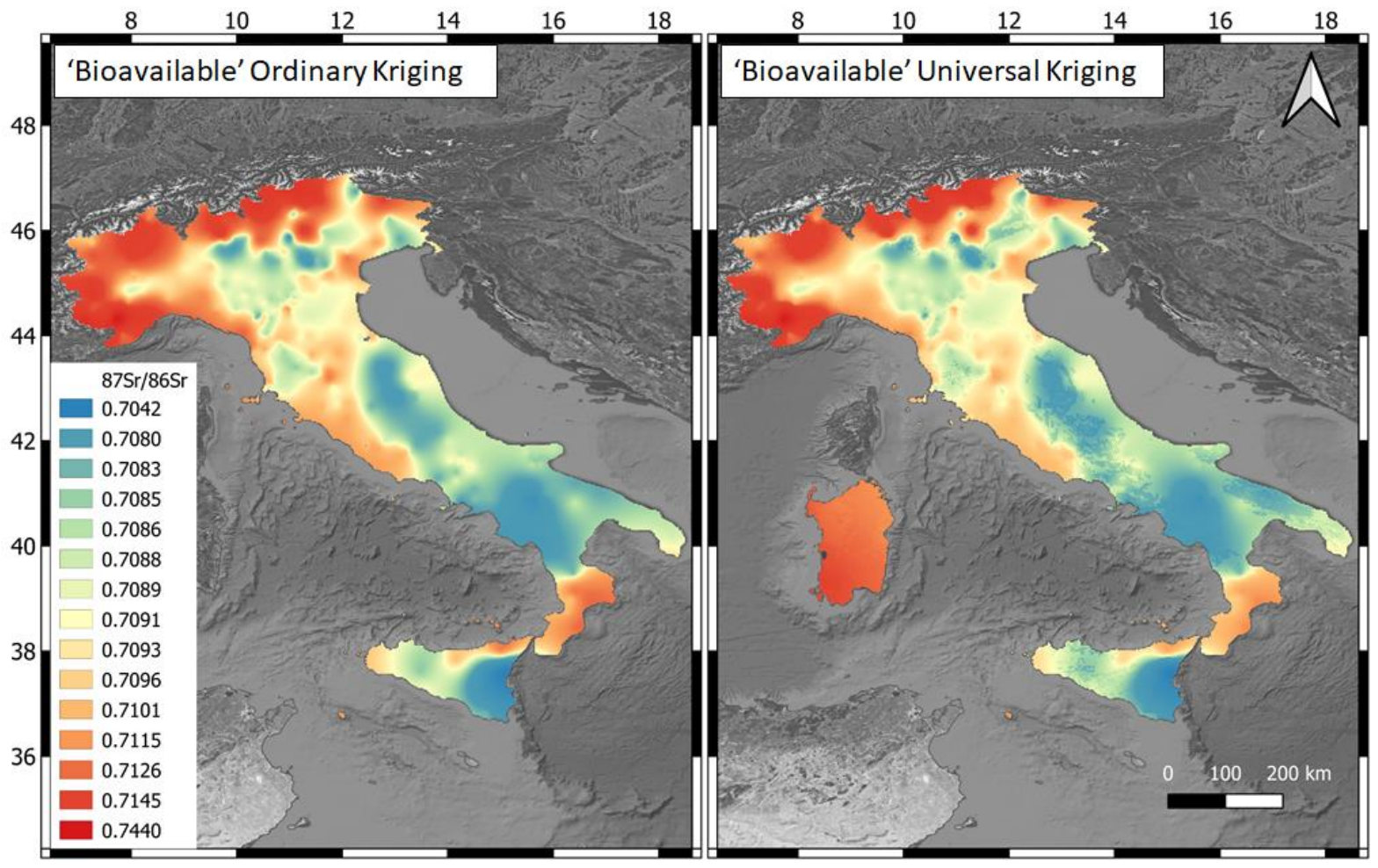

Figure 4. Ordinary and Universal (with external drift) kriging models obtained for the 'bioavailable ${ }^{87} \mathrm{Sr} /{ }^{86} \mathrm{Sr}$ dataset. Maps were obtained using SAGA 7.9 and QGIS 3.8. 


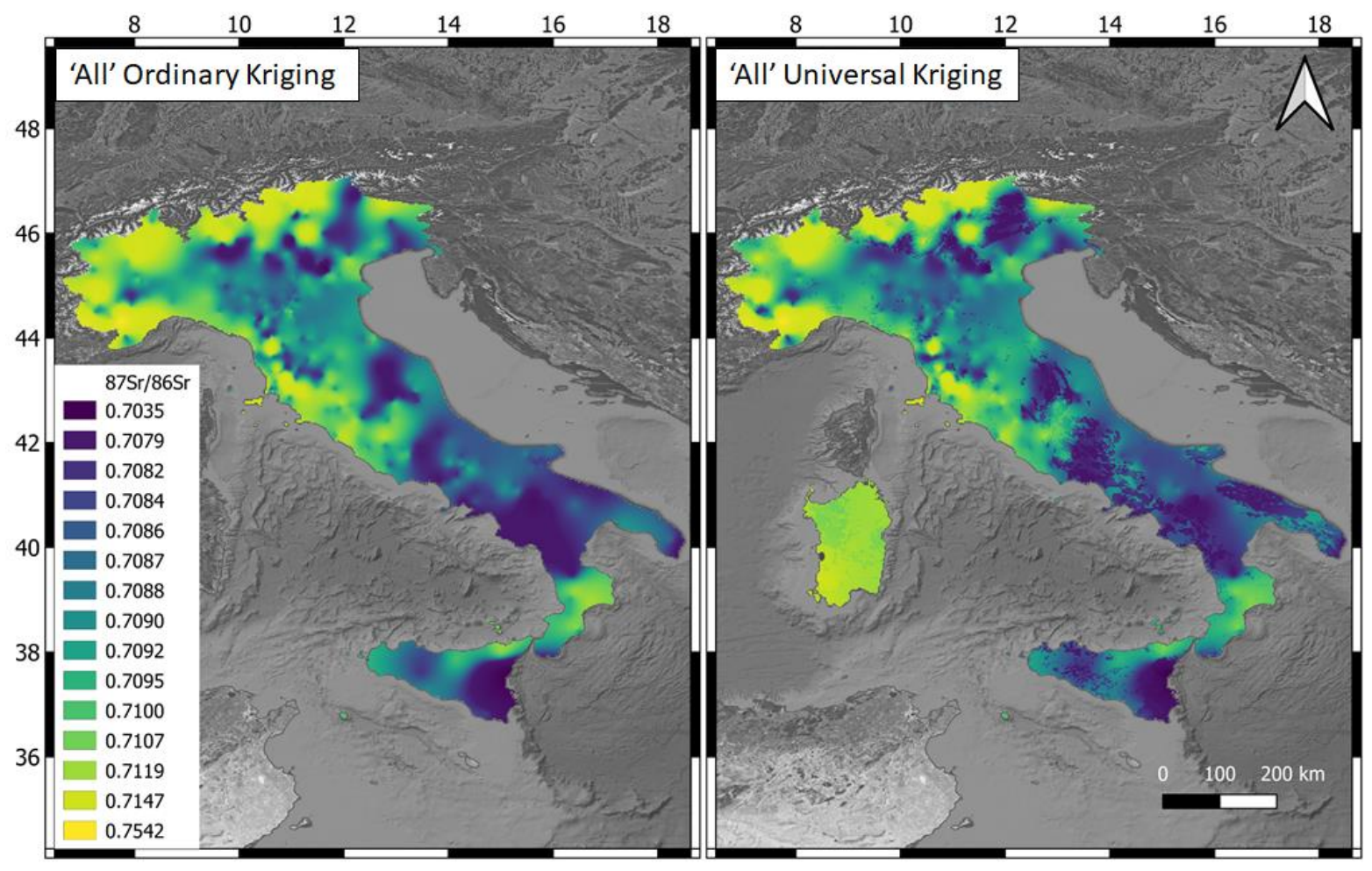

268 Figure 5. Ordinary and Universal (with external drift) kriging models obtained for the 'all' ${ }^{87} \mathrm{Sr} /{ }^{86} \mathrm{Sr}$ dataset. Maps were 269 obtained using SAGA 7.9 and QGIS 3.8.

271 The 'bioavailable' (Figure 4) and the 'all' (Figure 5) maps show similar spatial distribution of the ${ }^{87} \mathrm{Sr} /{ }^{86} \mathrm{Sr}$ ratios,

272 with the highest radiogenic values clustered in well-defined geological areas of Italy, namely the Alps, the Tuscan

273 Magmatic Province, the Latium volcanic area and the Calabria crystalline basement (Southern Italy). These values

274 are of course related to the radiogenic nature of the natural components from these areas included in our database.

275 Contrariwise, low $\mathrm{Sr}$ isotope values are generally present in areas characterized by depleted mantle magmatism 276 such as in Sicily and in Campania and where old carbonates (older than Pliocene) outcrop.

277 The largest differences in terms of isoscape predicted values among the 'all' and the 'bioavailable' maps arise indeed 278 in these areas (particularly Tuscany and Latium), due to the presence of even higher radiogenic values in local 279 rocks, only partially identified in the bioavailable pool (see Figure S5). The north-western Alpine area also shows 280 significant differences (both in negative and positive) between the two datasets. However, here, only few rock values are present within the 'all' database. This suggests that the observed variations (see e.g. Cuneo area, north- 
282

283

284

western Italy) are probably linked to model's predictions inaccuracies rather than actual variations of the ${ }^{87} \mathrm{Sr} /{ }^{86} \mathrm{Sr}$ ratio.

Overall, several small 'hotspots' (both negative and positive) can be recognized when comparing the predictions of the two datasets, particularly in the Alps. We stress that the number of samples in these areas is lower than in other localities; however, another explanation might lie in the complex geometry of the Alps where the bioavailable Sr isotope ratios might differ from those of the exposed rocks because of the geological complexity of the nappes that overthrust each other in the belt and therefore in the differential contributions to the bioavailable Sr possibly from other reservoirs.

Sharper details of the isotope zones can be observed in the Universal Kriging map compared to the Ordinary Kriging, due to the definite isoclass boundaries of the guiding map. In general, when looking at specific areas of the map, the Universal Kriging model should be more accurate in terms of spatial prediction, particularly for those areas with few data available. However, the Ordinary Kriging map seems to better mimic the natural averaging of Sr isotope values due to weathering and mixing processes.

\subsection{Definition of the local bioavailable Sr baseline for human provenance: a case study}

Defining the local bioavailable Sr baseline is currently a hot topic in archaeology and anthropology. Common methods include the measurement of modern environmental samples as waters, plants, snail shells and soil leachates (Bentley, 2006; Maurer et al., 2012; Ladegaard-Pedersen et al., 2020; Toncala et al., 2020), but also through the analysis of local (archaeological) fauna (see e.g. Lugli et al., 2019). Some studies also showed the power of using statistical methods to detect outliers (as Tukey's fences and median absolute deviations) among the human's skeletal isotopic dataset, to constrain local vs. non-local individuals (Lightfoot and O'Connell, 2016; Cavazzuti et al., 2021). Once defined, the local baseline is then used to comprehend the mobility patterns of the investigated human population (i.e. autochthonous vs. allochthonous individuals). However, there is no general consensus on the best practices to employ for determining the local Sr baseline (e.g. Maurer et al., 2012; Britton et al., 2020; Weber et al., 2021). All the methods have indeed intrinsic flaws linked to various sources of error such as anthropogenic contaminations on environmental samples (Thomsen and Andreasen, 2019), temporal changes in the Sr mixing end-members (e.g. Erel and Torrent, 2010; Han et al., 2019) or simply erroneous a priori assumptions. For example, were 'local' animals actually 'local'? What is their real home range? Are modern plants, 
310 growing on modern soils, isotopically representative of the ancient landscape? All these are open questions that 311 call for further investigations and can lead to data misinterpretation if not considered.

312 We take advantage of some of the novel data measured for this study to further discuss this issue, focusing on the 313 Bronze Age archaeological site of Fratta Polesine (Cardarelli et al., 2015; Cavazzuti et al., 2019a) in the Po plain 314 (Northern Italy). Locally, the geology is characterized by Holocene alluvial debris, mainly composed of siliciclastic 315 sedimentary deposits related to the erosion of the Alpine belt. We built a bioavailable $\mathrm{Sr}$ isoscape excluding the 316 bioavailable data from the site, to compare the Ordinary Kriging interpolated data against the Fratta Polesine 317 measured dataset (Figure 6). The Ordinary Kriging interpolated ${ }^{87} \mathrm{Sr} /{ }^{86} \mathrm{Sr}$ ratio, in a radius of $10 \mathrm{~km}$ from the site, 318 ranges between 0.7091 and 0.7096 , with a median value of 0.7094 . The measured bioavailable data from Fratta 319 Polesine are averagely less radiogenic (0.7089) but more variable, ranging between 0.7085 (snail) and 0.7094 320 (modern shallow rooted plant). These specimens plot as three distinct clusters, with plant and soils showing the 321 highest values (0.7092-0.7094), snails the lowest (0.7085-0.7086), and animal enamel falling in the middle (0.7088322 0.7089). Such variability in our measured data suggests that different end-members influenced in different ways 323 the environmental specimens. Plants (mostly shallow rooted plants) and soils are indeed likely to be more 324 influenced by atmospheric deposition and anthropogenic contaminants. Yet, the rainwaters from the Apennines 325 show a maximum value of 0.7092 (Table 2), suggesting that other sources (as dust, fertilizers and/or other antropic 326 sources) might have contributed to the plant-soil pool at Fratta Polesine (Thomsen and Andreasen, 2019). Our 327 isoscape agrees with the presence of higher radiogenic values towards the north-east. Hence, we can alternatively 328 hypothesize that underground waters flowing southwards from the Alps into the Po plain might have influenced 329 the local isotope fingerprint of soils and plants from Fratta Polesine.

330 Snail shells are characterized by the lowest radiogenic ${ }^{87} \mathrm{Sr} /{ }^{86} \mathrm{Sr}$ ratios among the measured samples. This has been 331 observed before in the literature (Maurer et al., 2012; Britton et al., 2020), and linked to the amount of soil 332 carbonate (up to 40\%) incorporated into the diet of land snails (Yanes et al., 2008; Maurer et al., 2012). Animal 333 enamel shows intermediate values, possibly reflecting different sources of drinking water and food (Toncala et al., 334 2020). For example, the (domesticated?) dog and pig teeth are isotopically compatible with the Po river water, one 335 of the main sources of drinking water close to Fratta Polesine. Human data presented in Cavazzuti et al. (2019a) 336 show a median ${ }^{87} \mathrm{Sr} /{ }^{86} \mathrm{Sr}$ ratio of 0.7089 , with an interquartile range (Q3-Q1) of 0.0006 , indicating that most of 337 the individuals are compatible with the baseline of the site and few plot outside the local environmental variability 338 (see Cavazzuti et al., 2019a for more details). 


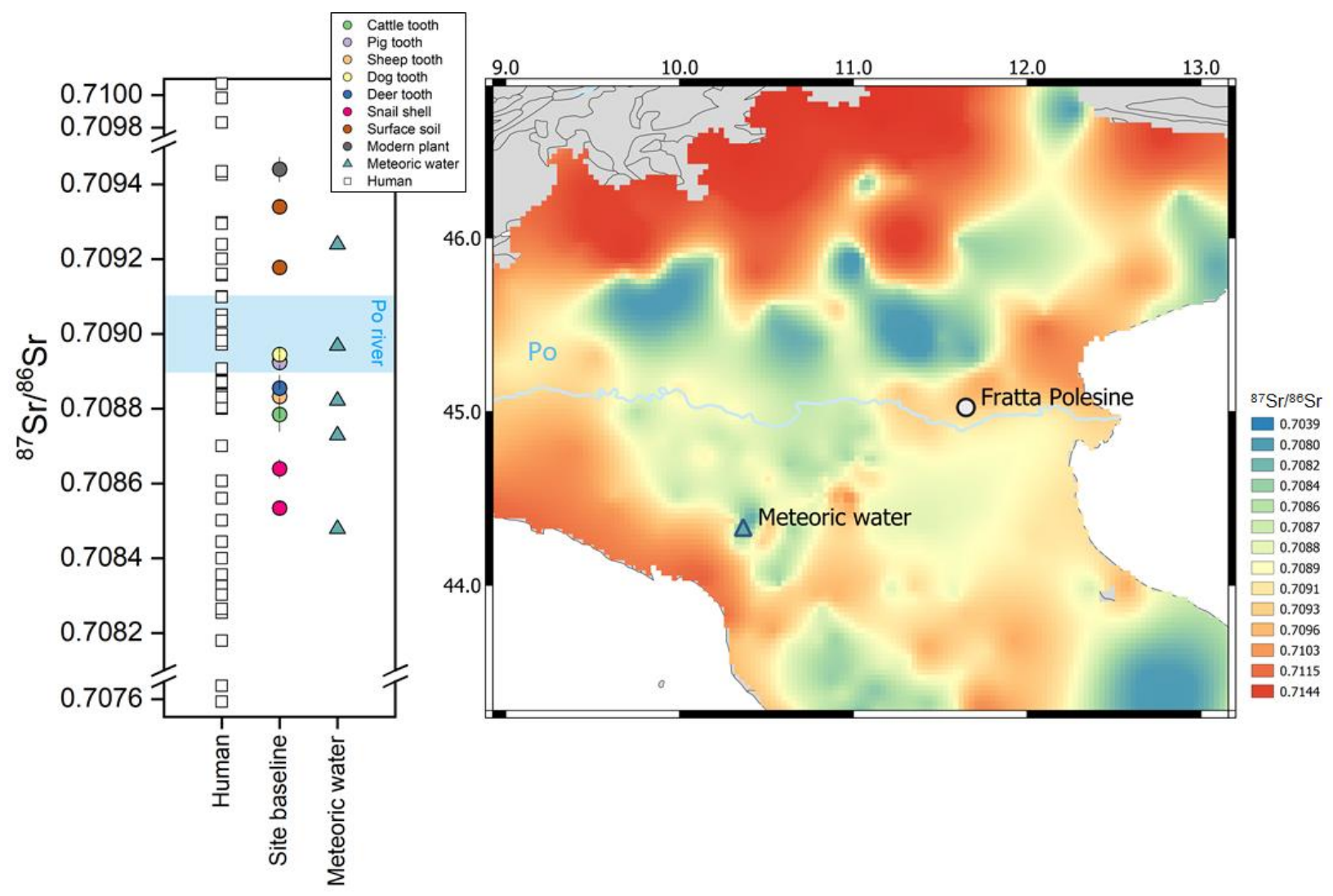

Figure 6. Local baseline at the Bronze Age site of Fratta Polesine (Rovigo, Veneto). Analysed samples include animal tooth enamel, snail shells, surface soil leachates and vegetation. Human data (including both enamel and cremated petrous bone specimens) are from Cavazzuti et al. (2019a). In the graph, meteoric water data from the Apennines (blue triangles) and water data (light blue area) from the Po river (sampling locations close to the site) are reported for comparison. The Sr bioavailable map on the right panel is an Ordinary Kriging interpolation, without the local data from Fratta Polesine. The local $(<10 \mathrm{~km})$ predicted ${ }^{87} \mathrm{Sr} /{ }^{86} \mathrm{Sr}$ range at the site is $0.7091-0.7096$ (median 0.7094). The Po river is also shown on the map.

Overall, these data suggest that soils (leachates) and plants best reflect the local bioavailable Sr pool, although possibly contaminated by modern and/or antropic end-members. Fauna enamel, if truly local as in the case of domesticated macro-mammals or small home range micro-mammals, mixes various bioavailable Sr sources and more closely mimics the local food and drinking sources. Such evidence clearly highlights the intrinsic limits in using isoscapes, which are commonly composed by a patchwork of literature data from different samples, or modelled on specific samples collected ad hoc (as soils or plants). Yet, we stress here that Sr isotopes need to be interpreted following an 'exclusion' principle, and thus employed to discard possible areas as point of origin (Holt 
354 et al., 2021). This, in turn, suggests that provenancing through isoscapes, and isotope baselines in general, need to

355 be performed with caution. Hence, isoscapes must be considered as 'guides' for data interpretation, rather than

356 an unequivocal provenancing tool, justifying their composite nature to better understand the variability of local 357 Sr pools.

We collected a large amount of georeferenced Sr isotope values for Italy. Owing to this database, we were able to produce ${ }^{87} \mathrm{Sr} /{ }^{86} \mathrm{Sr}$ prediction maps by geostatistical modelling, namely Ordinary Kriging and Universal Kriging. Model performances were evaluated through 10-fold cross validations, resulting in RMSE ranging between 0.0020 and 0.0024 .

364 Bioavailable Sr isotope values across Italy show a remarkable variability, with the Alps and certain metamorphic/magmatic terrains displaying the highest radiogenic values, and are in general well-consistent with the underlying bedrock type.

We took advantage of the produced maps to discuss a local case study and the definition of local baseline in archaeological studies, a currently hot-topic within the field of provenance and mobility studies. In this sense, regional and (extra)national isoscapes are key in understanding the variability of the local Sr pool, broadening our understanding on the mixing of the different end-members to obtain certain isotope signatures in (geo)biological samples.

372 Distribution maps of $\mathrm{Sr}$ isotopes provide a solid interpretative basis for provenance and traceability studies. Our 373 maps and database are freely accessible online and will be updated in the future when new data become available.

374 In this sense, we will continue to collect and analyse new environmental samples from low-density areas (such as 375 Sicily and Sardinia) to improve the prediction power of the models. In addition, we plan to employ novel methods

376 for the spatial modelling of isotope data, using different predictors and machine learning approaches. 
379

380

381

382

383

384

385

386

387

388

389

390

391

392

393

394

395

396

397

398

399

400

401

402

403

The Geochemistry Lab at the University of Modena and Reggio Emilia has been funded through a grant of the Programma Giovani Ricercatori Rita Levi Montalcini to AC. This project received funds by the European Research Council (ERC) under the European Union's Horizon 2020 Research and Innovation Programme (grant agreement No 724046 - SUCCESS awarded to SB) and the MIUR FARE programme 2018 (FARE Ricerca in Italia: Framework per l'attrazione e il rafforzamento delle eccellenze - SAPIENS project to SB). Mattia Sisti is thanked for initiating the collection of Sr isotope data and Silvia Cercatillo for water sampling.

\section{References}

Adams, S., Grün, R., McGahan, D., Zhao, J., Feng, Y., Nguyen, A., Willmes, M., Quaresimin, M., Lobsey, B., Collard, M., 2019. A strontium isoscape of north-east Australia for human provenance and repatriation. Geoarchaeology 34, 231-251.

Argentino, C., Lugli, F., Cipriani, A., Panieri, G., 2021. Testing miniaturized extraction chromatography protocols for combined $87 \mathrm{Sr} / 86 \mathrm{Sr}$ and $888 / 86 \mathrm{Sr}$ analyses of pore water by MC-ICP-MS. Limnol. Oceanogr. Methods 19, 431-440.

Bataille, C.P., Bowen, G.J., 2012. Mapping 87Sr/86Sr variations in bedrock and water for large scale provenance studies. Chem. Geol. 304, 39-52.

Bataille, C.P., Von Holstein, I.C.C., Laffoon, J.E., Willmes, M., Liu, X.-M., Davies, G.R., 2018. A bioavailable strontium isoscape for Western Europe: A machine learning approach. PLoS One 13, e0197386.

Bataille, C.P., Jaouen, K., Milano, S., Trost, M., Steinbrenner, S., Crubézy, É., Colleter, R., 2021. Triple sulfuroxygen-strontium isotopes probabilistic geographic assignment of archaeological remains using a novel sulfur isoscape of western Europe. PLoS One 16, e0250383.

Bentley, R.A., 2006. Strontium isotopes from the earth to the archaeological skeleton: A review. J. Archaeol. Method Theory 13, 135-187.

Bowen, G.J., 2010. Isoscapes: spatial pattern in isotopic biogeochemistry. Annu. Rev. Earth Planet. Sci. 38, 161187. 
404

405

406

407

408

409

410

411

412

413

414

415

416

417

418

419

420

421

422

423

424

425

426

427

428

Britton, K., Le Corre, M., Willmes, M., Moffat, I., Grün, R., Mannino, M.A., Woodward, S., Jaouen, K., 2020. Sampling Plants and Malacofauna in 87Sr/86Sr Bioavailability Studies: implications for isoscape mapping and reconstructing of past mobility patterns. Front. Ecol. Evol. 8, 579473.

Capo, R.C., Stewart, B.W., Chadwick, O.A., 1998. Strontium isotopes as tracers of ecosystem processes: theory and methods. Geoderma 82, 197-225.

Cardarelli, A., Cavazzuti, C., Quondam, F., Salvadei, L., Salzani, L., 2015. Le necropoli delle Narde di Frattesina: proposta per una lettura delle evidenze demografiche, rituali e sociali a partire dai dati archeologici e antropologici. Le necropoli delle Narde di Frat. Propos. per una Lett. delle evidenze Demogr. Ritual. e Soc. a partire dai dati Archeol. e Antropol. 437-445.

Cavazzuti, C., Cardarelli, A., Quondam, F., Salzani, L., Ferrante, M., Nisi, S., Millard, A.R., Skeates, R., 2019 a. Mobile elites at Frattesina: flows of people in a Late Bronze Age 'port of trade' in northern Italy. Antiquity 93, $624-644$.

Cavazzuti, C., Skeates, R., Millard, A.R., Nowell, G., Peterkin, J., Brea, M.B., Cardarelli, A., Salzani, L., $2019 b$. Flows of people in villages and large centres in Bronze Age Italy through strontium and oxygen isotopes. PLoS One 14, e0209693.

Cavazzuti, C., Hajdu, T., Lugli, F., Sperduti, A., Vicze, M., Horváth, A., Major, I., Molnár, M., Palcsu, L., Kiss, V., 2021. Human mobility in a Bronze Age Vatya 'urnfield' and the life history of a high-status woman. PLoS One $16, \mathrm{e} 0254360$.

Chesson, L.A., Tipple, B.J., Ehleringer, J.R., Park, T., Bartelink, E.J., 2018. Forensic applications of isotope landscapes ("isoscapes”): a tool for predicting region-of-origin in forensic anthropology cases. Forensic Anthropol. Theor. Framew. Sci. basis $127-148$.

Colleter, R., Bataille, C.P., Dabernat, H., Pichot, D., Hamon, P., Duchesne, S., Labaune-Jean, F., Jean, S., Le Cloirec, G., Milano, S., 2021. The last battle of Anne of Brittany: solving mass grave through an interdisciplinary approach (paleopathology, biological anthropology, history, multiple isotopes and radiocarbon dating). PLoS One 16, e0248086. 
429 Copeland, S.R., Cawthra, H.C., Fisher, E.C., Lee-Thorp, J.A., Cowling, R.M., le Roux, P.J., Hodgkins, J., 430 Marean, C.W., 2016. Strontium isotope investigation of ungulate movement patterns on the Pleistocene Paleo431 Agulhas Plain of the Greater Cape Floristic Region, South Africa. Quat. Sci. Rev. 141, 65-84.

432 Ehrlich, S., Gavrieli, I., Dor, L.-B., Halicz, L., 2001. Direct high-precision measurements of the 87 Sr/86 Sr isotope 433 ratio in natural water, carbonates and related materials by multiple collector inductively coupled plasma mass 434 spectrometry (MC-ICP-MS). J. Anal. At. Spectrom. 16, 1389-1392.

435 Emery, M. V, Stark, R.J., Murchie, T.J., Elford, S., Schwarcz, H.P., Prowse, T.L., 2018. Mapping the origins of 436 Imperial Roman workers (1st-4th century CE) at Vagnari, Southern Italy, using $87 \mathrm{Sr} / 86 \mathrm{Sr}$ and d18O variability. 437 Am. J. Phys. Anthropol. 166, 837-850.

438 Erel, Y., Torrent, J., 2010. Contribution of Saharan dust to Mediterranean soils assessed by sequential extraction 439 and $\mathrm{Pb}$ and $\mathrm{Sr}$ isotopes. Chem. Geol. 275, 19-25.

440 Ericson, J., 1985. Strontium isotope characterization in the study of prehistoric human ecology. J. Hum. Evol. 14, $441503-514$.

442 Evans, J.A., Montgomery, J., Wildman, G., Boulton, N., 2010. Spatial variations in biosphere 87Sr/86Sr in 443 Britain. J. Geol. Soc. London. 167, 1-4.

444 Faure, G., Mensing, T.M., 2005. Isotopes: principles and applications, 3rd ed. John Wiley \& Sons, Hoboken, New 445 Jersey.

446 Frank, A.B., Frei, R., Moutafi, I., Voutsaki, S., Orgeolet, R., Kristiansen, K., Frei, K.M., 2021. The geographic 447 distribution of bioavailable strontium isotopes in Greece-A base for provenance studies in archaeology. Sci. Total 448 Environ. 148156.

449 Frei, K.M., Frei, R., 2011. The geographic distribution of strontium isotopes in Danish surface waters - A base for 450 provenance studies in archaeology, hydrology and agriculture. Appl. Geochemistry 26, 326-340.

451 Funck, J., Bataille, C., Rasic, J., Wooller, M., 2021. A bio-available strontium isoscape for eastern Beringia: a tool 452 for tracking landscape use of Pleistocene megafauna. J. Quat. Sci. 36, 76-90. 
453 Gregoricka, L.A., 2021. Moving Forward: A Bioarchaeology of Mobility and Migration. J. Archaeol. Res. doi: 454 10.1007/s10814-020-09155-9.

455 Han, G., Song, Z., Tang, Y., Wu, Q., Wang, Z., 2019. Ca and Sr isotope compositions of rainwater from Guiyang 456 city, Southwest China: Implication for the sources of atmospheric aerosols and their seasonal variations. Atmos. 457 Environ. 214, 116854.

458 Hartman, G., Richards, M., 2014. Mapping and defining sources of variability in bioavailable strontium isotope 459 ratios in the Eastern Mediterranean. Geochim. Cosmochim. Acta 126, 250-264.

460 Hedman, K.M., Slater, P.A., Fort, M.A., Emerson, T.E., Lambert, J.M., 2018. Expanding the strontium isoscape 461 for the American midcontinent: Identifying potential places of origin for Cahokian and Pre-Columbian migrants. 462 J. Archaeol. Sci. Reports 22, 202-213.

463 Hobson, K.A., Barnett-Johnson, R., Cerling, T., 2010. Using isoscapes to track animal migration, in: Isoscapes. 464 Springer, pp. 273-298.

465 Holt, E., Evans, J.A., Madgwick, R., 2021. Strontium (87Sr/86Sr) mapping: a critical review of methods and 466 approaches. Earth-Science Rev. 103593.

467 Hoogewerff, J.A., Reimann, C., Ueckermann, H., Frei, R., Frei, K.M., van Aswegen, T., Stirling, C., Reid, M., 468 Clayton, A., Ladenberger, A., 2019. Bioavailable 87 Sr/ 86 Sr in European soils: A baseline for provenancing 469 studies. Sci. Total Environ. 672, 1033-1044.

470 Killick, D.J., Stephens, J.A., Fenn, T.R., 2020. Geological constraints on the use of lead isotopes for provenance 471 in archaeometallurgy. Archaeometry 62, 86-105.

472 Knudson, K.J., Williams, H.M., Buikstra, J.E., Tomczak, P.D., Gordon, G.W., Anbar, A.D., 2010. Introducing $473 \delta 88 / 86 \mathrm{Sr}$ analysis in archaeology: a demonstration of the utility of strontium isotope fractionation in paleodietary 474 studies. J. Archaeol. Sci. 37, 2352-2364.

475 Kootker, L.M., van Lanen, R.J., Kars, H., Davies, G.R., 2016. Strontium isoscapes in The Netherlands. Spatial 476 variations in $87 \mathrm{Sr} / 86 \mathrm{Sr}$ as a proxy for palaeomobility. J. Archaeol. Sci. Reports 6, 1-13. 
477 Krige, D.G., 1951. A statistical approach to some basic mine valuation problems on the Witwatersrand. J. South.

478 African Inst. Min. Metall. 52, 119-139.

479 Ladegaard-Pedersen, P., Achilleos, M., Dörflinger, G., Frei, R., Kristiansen, K., Frei, K.M., 2020. A strontium 480 isotope baseline of Cyprus. Assessing the use of soil leachates, plants, groundwater and surface water as proxies 481 for the local range of bioavailable strontium isotope composition. Sci. Total Environ. 708, 134714.

482 Laffoon, J.E., Sonnemann, T.F., Shafie, T., Hofman, C.L., Brandes, U., Davies, G.R., 2017. Investigating human 483 geographic origins using dual-isotope $(87 \mathrm{Sr} / 86 \mathrm{Sr}, \delta 18 \mathrm{O})$ assignment approaches. PLoS One 12, e0172562.

484 Lazzerini, N., Balter, V., Coulon, A., Tacail, T., Marchina, C., Lemoine, M., Bayarkhuu, N., Turbat, T., Lepetz, 485 S., Zazzo, A., 2021. Monthly mobility inferred from isoscapes and laser ablation strontium isotope ratios in 486 caprine tooth enamel. Sci. Rep. 11, 1-11.

487 Lightfoot, E., O’Connell, T.C., 2016. On the use of biomineral oxygen isotope data to identify human migrants 488 in the archaeological record: intra-sample variation, statistical methods and geographical considerations. PLoS 489 One 11, e0153850.

490 Lugli, F., Cipriani, A., Peretto, C., Mazzucchelli, M., Brunelli, D., 2017. In situ high spatial resolution 87Sr/86Sr 491 ratio determination of two Middle Pleistocene (c.a. $580 \mathrm{ka})$ Stephanorhinus hundsheimensis teeth by LA-MC492 ICP-MS. Int. J. Mass Spectrom. 412, 38-48.

493 Lugli, F., Cipriani, A., Capecchi, G., Ricci, S., Boschin, F., Boscato, P., Iacumin, P., Badino, F., Mannino, M.A., 494 Talamo, S., Richards, M.P., Benazzi, S., Ronchitelli, A., 2019. Strontium and stable isotope evidence of human 495 mobility strategies across the Last Glacial Maximum in southern Italy. Nat. Ecol. Evol. 3, 905-911.

496 Maurer, A., Galer, S.J.G., Knipper, C., Beierlein, L., Nunn, E. V, Peters, D., Tütken, T., Alt, K.W., Schöne, B.R., 497 2012. Bioavailable 87Sr/86Sr in different environmental samples - Effects of anthropogenic contamination and 498 implications for isoscapes in past migration studies. Sci. Total Environ. 433, 216-229.

499 McArthur, J.M., Howarth, R.J., Bailey, T.R., 2001. Strontium isotope stratigraphy: LOWESS version 3: best fit 500 to the marine Sr-isotope curve for 0-509 Ma and accompanying look-up table for deriving numerical age. J. Geol. $501 \quad 109,155-170$. 
502 Montgomery, J., Evans, J. a., Wildman, G., 2006. 87Sr/86Sr isotope composition of bottled British mineral waters 503 for environmental and forensic purposes. Appl. Geochemistry 21, 1626-1634.

504 Muhlfeld, C.C., Thorrold, S.R., McMahon, T.E., Marotz, B., 2012. Estimating westslope cutthroat trout 505 (Oncorhynchus clarkii lewisi) movements in a river network using strontium isoscapes. Can. J. Fish. Aquat. Sci. $506 \quad 69,906-915$.

507 Négrel, P., Guerrot, C., Millot, R., 2007. Chemical and strontium isotope characterization of rainwater in France: 508 influence of sources and hydrogeochemical implications. Isotopes Environ. Health Stud. 43, 179-196.

509 Oliver, M.A., Webster, R., 1990. Kriging: a method of interpolation for geographical information systems. Int. J. 510 Geogr. Inf. Syst. 4, 313-332.

511 Pederzani, S., Britton, K., 2019. Oxygen isotopes in bioarchaeology: Principles and applications, challenges and 512 opportunities. Earth-Science Rev. 188, 77-107.

513 Pellegrini, M., Pouncett, J., Jay, M., Pearson, M.P., Richards, M.P., 2016. Tooth enamel oxygen “isoscapes” show 514 a high degree of human mobility in prehistoric Britain. Sci. Rep. 6, 34986.

515 Pestle, W.J., Simonetti, A., Curet, L.A., 2013. 87Sr/86Sr variability in Puerto Rico: geological complexity and the 516 study of paleomobility. J. Archaeol. Sci. 40, 2561-2569.

517 Pors Nielsen, S., 2004. The biological role of strontium. Bone 35, 583-8.

518 Scaffidi, B.K., Knudson, K.J., 2020. An archaeological strontium isoscape for the prehistoric Andes: 519 Understanding population mobility through a geostatistical meta-analysis of archaeological $87 \mathrm{Sr} / 86 \mathrm{Sr}$ values 520 from humans, animals, and artifacts. J. Archaeol. Sci. 117, 105121.

521 Sillen, A., Hall, G., Richardson, S., Armstrong, R., 1998. 87Sr/86Sr ratios in modern and fossil food-webs of the 522 Sterkfontein Valley: implications for early hominid habitat preference. Geochim. Cosmochim. Acta 62, 24635232473.

524 Slovak, N.M., Paytan, A., 2012. Applications of Sr Isotopes in Archaeology, in: Baskaran, M. (Ed.), Handbook of 525 Environmental Isotope Geochemistry. Springer, pp. 743-768. 
526 Smith, K.E., Weis, D., Amini, M., Shiel, A.E., Lai, V.W.-M., Gordon, K., 2019. Honey as a biomonitor for a 527 changing world. Nat. Sustain. 2, 223-232.

528 Snoeck, C., Ryan, S., Pouncett, J., Pellegrini, M., Claeys, P., Wainwright, A.N., Mattielli, N., Lee-Thorp, J.A., 529 Schulting, R.J., 2020. Towards a biologically available strontium isotope baseline for Ireland. Sci. Total Environ. $530712,136248$.

531 Song, B.-Y., Ryu, J.-S., Shin, H.S., Lee, K.-S., 2014. Determination of the source of bioavailable Sr using 87Sr/86Sr 532 tracers: a case study of hot pepper and rice. J. Agric. Food Chem. 62, 9232-9238.

533 Soto, D.X., Wassenaar, L.I., Hobson, K.A., 2013. Stable hydrogen and oxygen isotopes in aquatic food webs are 534 tracers of diet and provenance. Funct. Ecol. 27, 535-543.

535 Thomsen, E., Andreasen, R., 2019. Agricultural lime disturbs natural strontium isotope variations: Implications 536 for provenance and migration studies. Sci. Adv. 5, eaav8083.

537 Tommasini, S., Marchionni, S., Tescione, I., Casalini, M., Braschi, E., Avanzinelli, R., Conticelli, S., 2018. 538 Strontium isotopes in biological material: A key tool for the geographic traceability of foods and humans beings, 539 in: Behaviour of Strontium in Plants and the Environment. Springer, pp. 145-166.

540 Toncala, A., Trautmann, B., Velte, M., Kropf, E., Mcglynn, G., 2020. On the premises of mixing models to define 541 local bioavailable 87Sr / 86Sr ranges in archaeological contexts. Sci. Total Environ. 745, 140902.

542 Vautour, G., Poirier, A., Widory, D., 2015. Tracking mobility using human hair: What can we learn from lead 543 and strontium isotopes? Sci. Justice 55, 63-71.

544 Voerkelius, S., Lorenz, G.D., Rummel, S., Quétel, C.R., Heiss, G., Baxter, M., Brach-Papa, C., Deters-Itzelsberger, 545 P., Hoelzl, S., Hoogewerff, J., Ponzevera, E., Van Bocxstaele, M., Ueckermann, H., 2010. Strontium isotopic 546 signatures of natural mineral waters, the reference to a simple geological map and its potential for authentication 547 of food. Food Chem. 118, 933-940.

548 Wang, X., Tang, Z., 2020. The first large-scale bioavailable Sr isotope map of China and its implication for 549 provenance studies. Earth-Science Rev. 103353. 
550 Washburn, E., Nesbitt, J., Ibarra, B., Fehren-Schmitz, L., Oelze, V.M., 2021. A strontium isoscape for the 551 Conchucos region of highland Peru and its application to Andean archaeology. PLoS One 16, e0248209.

552 Weber, M., Tacail, T., Lugli, F., Clauss, M., Weber, K., Leichliter, J., Winkler, D.E., Mertz-Kraus, R., Tütken, T., 553 2020. Strontium uptake and intra-population $87 \mathrm{Sr} / 86 \mathrm{Sr}$ variability of bones and teeth-controlled feeding 554 experiments with rodents (Rattus norvegicus, Cavia porcellus). Front. Ecol. Evol. 8, 569940.

555 Willmes, M., Bataille, C.P., James, H.F., Moffat, I., McMorrow, L., Kinsley, L., Armstrong, R.A., Eggins, S., 556 Grün, R., 2018. Mapping of bioavailable strontium isotope ratios in France for archaeological provenance studies. 557 Appl. Geochemistry 90, 75-86.

558 Yanes, Y., Delgado, A., Castillo, C., Alonso, M.R., Ibáñez, M., De la Nuez, J., Kowalewski, M., 2008. Stable 559 isotope $(\delta 18 \mathrm{O}, \delta 13 \mathrm{C}$, and $\delta \mathrm{D})$ signatures of recent terrestrial communities from a low-latitude, oceanic setting: 560 endemic land snails, plants, rain, and carbonate sediments from the eastern Canary Islands. Chem. Geol. 249, $561377-392$.

562 Zieliński, M., Dopieralska, J., Królikowska-Ciągło, S., Walczak, A., Belka, Z., 2021. Mapping of spatial variations 563 in $\mathrm{Sr}$ isotope signatures $(87 \mathrm{Sr} / 86 \mathrm{Sr}$ ) in Poland-Implications of anthropogenic Sr contamination for 564 archaeological provenance and migration research. Sci. Total Environ. 775, 145792. 


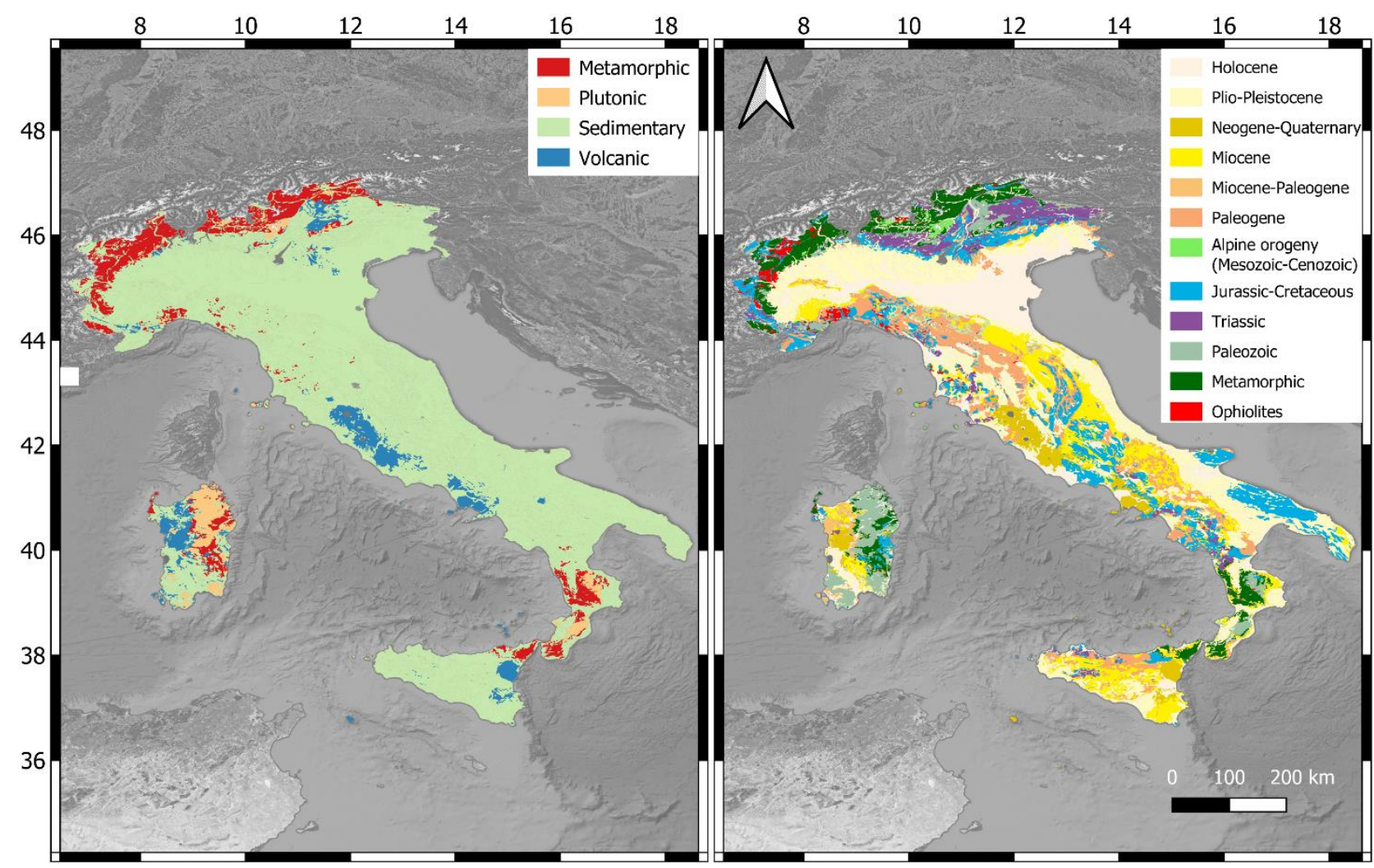

Figure S1. Geological maps of Italy. Left panel: formations are categorized by rock 'family'. Right panel: formations are categorized by age. This map is based on the geolithological map of Italy available at the Geoportale Nazionale (http://wms.pcn.minambiente.it/ogc?map=/ms_ogc/wfs/Carta_geolitologica.map); the satellite map is provided by Google through the QGIS QuickMapServices plug-in. 

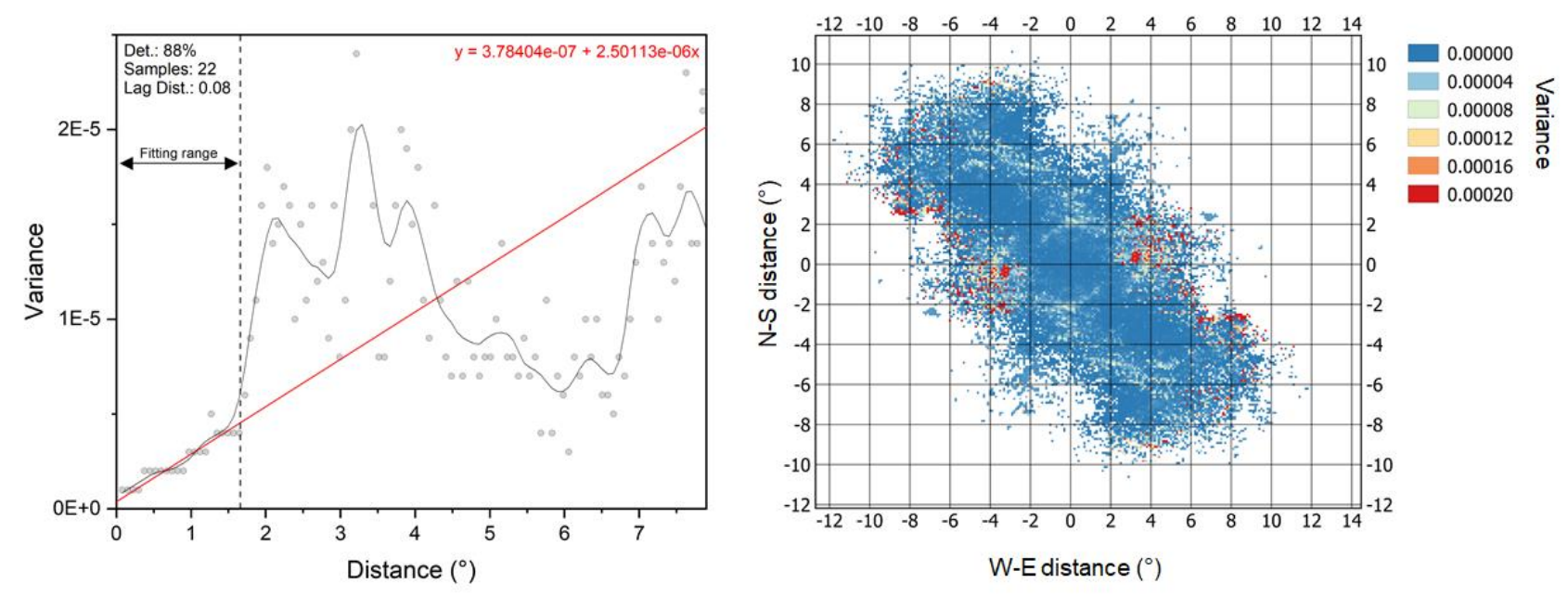

Figure S2. 'Bioavailable’ Ordinary Kriging variogram (biplot and surface) obtained through SAGA 7.9.

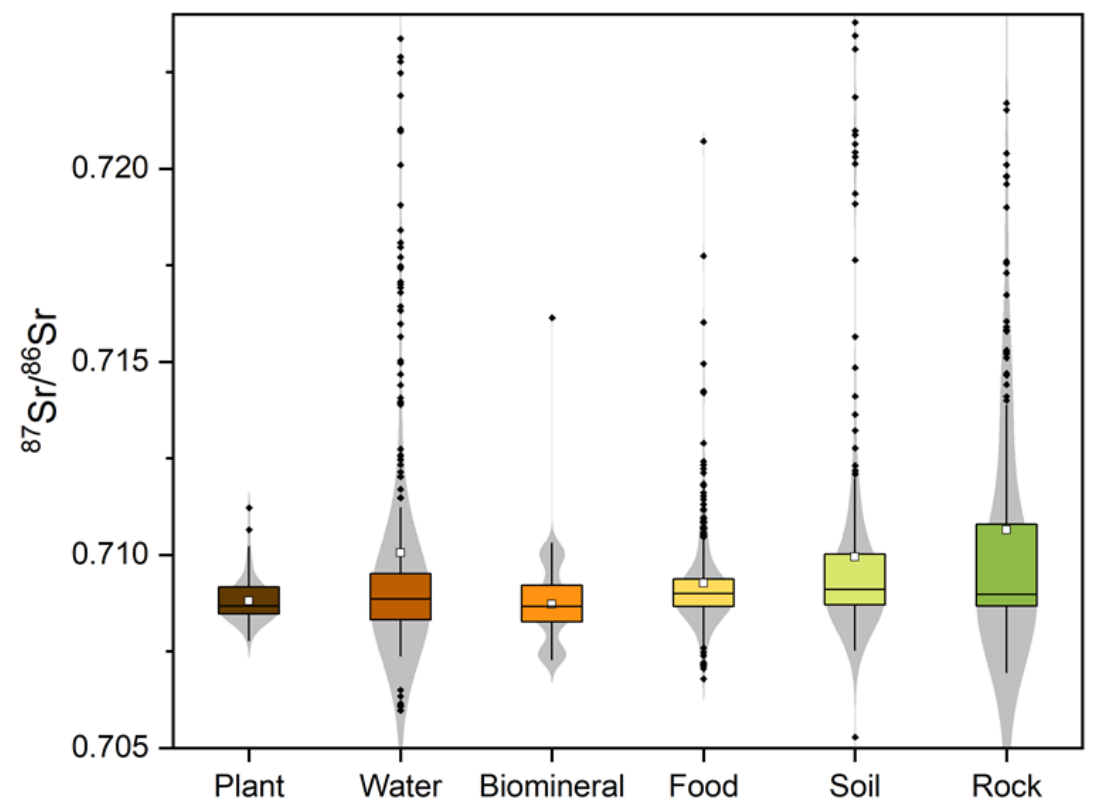

Figure S3. Box plot graph representing the ${ }^{8} \mathrm{Sr} /{ }^{8} \mathrm{Sr}$ ratios of the different sample categories. The gray shadows are data distributions obtained by kernel density estimations. Note that the graph is cut at 0.724 to improve readability, with some outliers plotting beyond the graph range. 


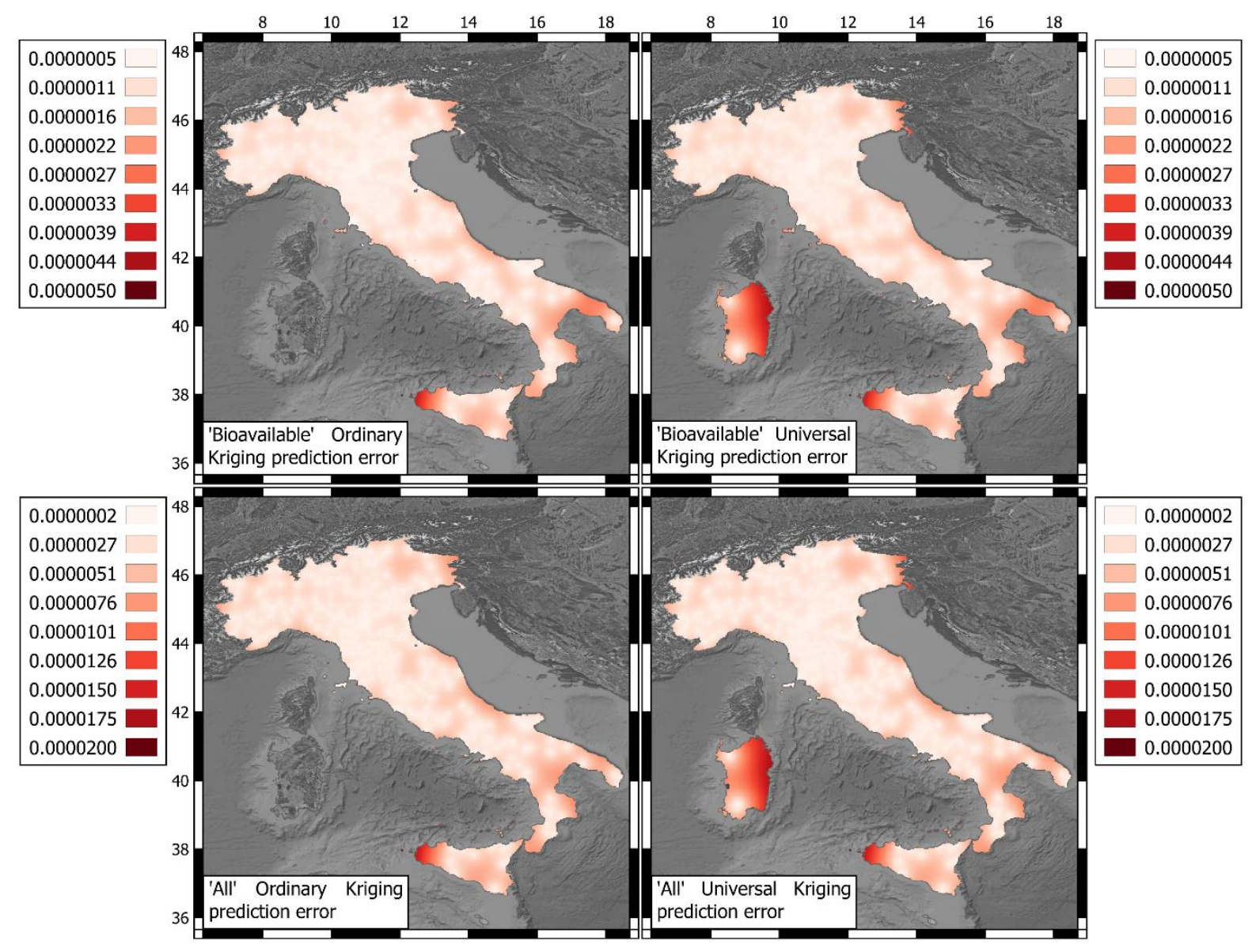

Figure S4. Prediction standard error for the Kriging models. Maps were obtained using SAGA 7.9 and QGIS 3.8. 


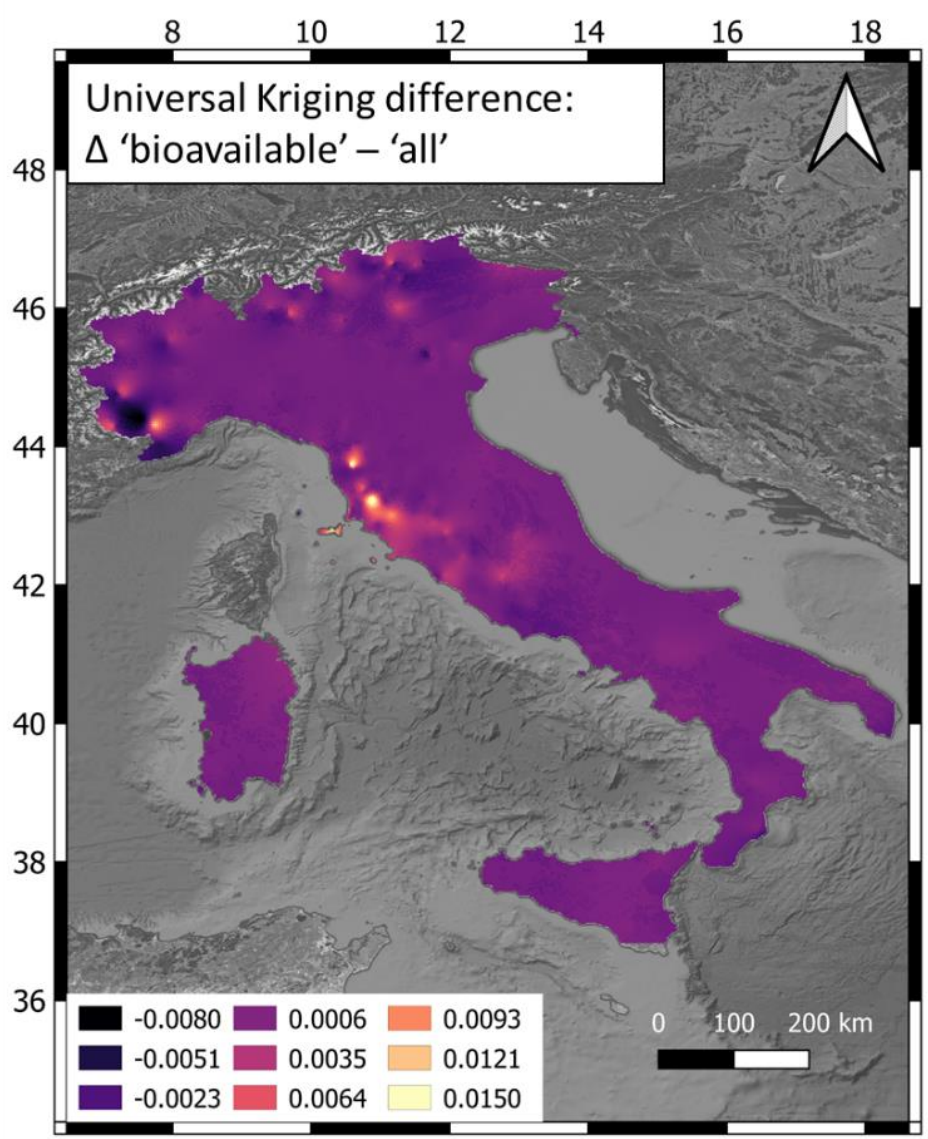

Figure S5. ${ }^{8} \mathrm{Sr} /{ }^{\star} \mathrm{S}$ S difference between 'all' and 'bioavailable' Universal Kriging models; e.g. a positive value means that Sr isotope data are higher in the 'all' map. Maps were obtained using SAGA 7.9 and QGIS 3.8. 
Table S1. Descriptive statistics for the whole dataset and (non-)bioavailable samples. 'Bioavailable' samples are 'plant', 'water', 'biomineral' and 'food' categories, in addition to 'soil' leachates. 'Non-bioavailable' samples are 'rock' and bulk 'soil'.

\begin{tabular}{|l|l|l|l|l|l|l|l|}
\hline Category & $\begin{array}{l}\mathrm{N} \\
\text { total }\end{array}$ & Mean & 2 SD & $\begin{array}{l}\text { Minimu } \\
\mathrm{m}\end{array}$ & Median & Maximum & $\begin{array}{l}\text { Interquartil } \\
\text { e Range (Q3 } \\
\text { - Q1) }\end{array}$ \\
\hline 'Bioavailable' & 1568 & 0.70941 & 0.00632 & 0.70354 & 0.70883 & 0.76384 & 0.00091 \\
\hline 'Non-bioavailable' & 352 & 0.71069 & 0.01054 & 0.70319 & 0.709 & 0.753 & 0.00223 \\
\hline 'All' & 1920 & 0.70964 & 0.00734 & 0.70319 & 0.70888 & 0.76384 & 0.00105 \\
\hline
\end{tabular}

